\title{
$\mathrm{NaCl}-\mathrm{H}_{3} \mathrm{BO}_{3}$ 水溶液における原子炉圧力容器材料の 加速腐食試験
}

\author{
金児紘征中川時子平泉浩成*
}

秋田大学大学院工学資源学研究科材料工学専攻

J. Japan Inst. Metals, Vol. 76, No. 11 (2012), pp. 615-623

(C) 2012 The Japan Institute of Metals

\section{Accelerated Corrosion Tests of Nuclear Reactor Pressure Vessel Materials in $\mathrm{NaCl}-\mathrm{H}_{3} \mathrm{BO}_{3}$ Solutions}

Hiroyuki Kaneko, Tokiko Nakagawa and Kousei Hiraizumi*

Department of Materials Science and Engineering, Graduate School of Engineering and Resource Science, Akita University, Akita 010-8502

Following the accident during 2011 at the Fukushima Daiichi nuclear plant, sea water for cooling and boric acid for maintaining a non-critical condition, both corrosive liquids, were injected into nuclear pressure vessels. In order to estimate corrosive characteristics of the pressure vessels an experimental study was undertaken to provide an accelerated corrosion test on SA533B low alloy steel and Inconel 600, materials used in the construction of the pressure vessels. In a typical experiment, samples of these materials were immersed in saturated $\mathrm{NaCl}$ and concentrated $\mathrm{H}_{3} \mathrm{BO}_{3}$ aqueous solutions at a temperature of $423 \mathrm{~K}$. SA533B suffered little or no corrosion in saturated $\mathrm{NaCl}$ solution, significant corrosion in concentrated $\mathrm{H}_{3} \mathrm{BO}_{3}$ and substantial corrosion in the binary saturated $\mathrm{NaCl}$-concentrated $\mathrm{H}_{3} \mathrm{BO}_{3}$ solution. Galvanic corrosion of SA533B was examined when Inconel 600 was also immersed in the same solution and the two samples were electrically connected either externally by a wire lead or internally by a screw made of Inconel 600 or both. Corrosion rate in the initial stage was $0.07 \mathrm{~mm} / \mathrm{h}$. The corrosion product on SA533B was porous and easily detachable, indicating corrosion to be progressive without producing a stable protective corrosion layer. The validity of the extreme experimental condition for accelerated corrosion tests is discussed and experimental programs for further investigation are proposed.

(Received April 26, 2012; Accepted August 6, 2012; Published November 1, 2012)

Keywords: nuclear accident, boiling water reactor, galvanic corrosion, crevice corrosion, SA533B

\section{1. 緒言}

2011 年 3 月 11 日に東京電力秼福島第一原子力発電所で 国際原子力事象評価尺度 (INES: International Nuclear Event Scale)レベル 7 の原子炉事故が発生した. その結果, 原子炉 圧力容器は冷却不能となり, 東京電力の解析によれば1), 核 燃料溶融の過程で激しく損傷し，1号炉では下部に穴が空い た可能性が高い。 また, 原子力安全・保安院の発表にあるよ うに2)，緊急に対処すべき状況の下で高温下で冷却のための 海水々再臨界防止のための “ホウ酸” が注入された. ここで “小ウ酸” と記したのは $\mathrm{H}_{3} \mathrm{BO}_{3}$ のことなのか, 他のホウ酸化 合物を含むものなのか，その性状が不明のためである。“小 ウ酸”はその後も断続的に注入された，正常な状況であれば 圧力容器内に本来ならば存在しないはずの高腐食性の海水や 余分の ‘ホウ酸” が存在することは, 圧力容器の耐食性面か らは深刻な事態であった， その後，冷却水に淡水が用いられ 冷温停止が図られているとは言え，事故発生初期には過酷な

* 秋田大学学生 (Undergraduate Student, Akita University)
状況であったことを勘案すると, 圧力容器の腐食性はどのよ うな状況であるかが懸念される，廃炉に至るまで安全に保持 しうるかについて，その腐食評価は緊急の課題である.

ところで，これまでこのような過酷事故下の圧力容器腐食 に対する知見はほとんどない. 1979 年に起ったレベル 5 の スリーマイル島原子力発電所事故では, 圧力容器に海水は注 入されなかったし, 圧力容器自体は破損しなかった。しか し, 圧力容器が $\mathrm{H}_{3} \mathrm{BO}_{3}$ によって激しく腐食することはよく 知られている. 2002 年にアメリカのデビスベッセ加圧水型 原子炉で定期点検中に低合金鋼の圧力容器の上蓋が激しく腐 食しているのが発見され，それは中性子制御用に注入された ホウ酸が耐食性のインコネル内張りの裂け目から流出したた めの腐食であることがわかった ${ }^{3)}$. その後, ホウ酸腐食につ いて徹底的に実験室的研究がなされたが4)，典型例では $370.5 \mathrm{~K}$ で大気開放下の濃厚ホウ酸水溶液中では, $40 \mathrm{~mm} / \mathrm{y}$ の激しい腐食速度であった。

事故を起こした福島第一原子力発電所の原子炉は沸騰水型 で, 圧力容器の本体は低合金鋼製で, 全体がステンレス鋼で 内張りされ, 下部の一部の内張りおよび制御棒被覆管との溶 接部は耐食性のニッケル基超合金製である。したがって，圧 
力容器が損傷して耐食性の内張りが破れた箇所があれば，低 合金鋼の腐食が始まり，低合金鋼と内張りとの間にガルバニ 対が形成されてガルバニ腐食の起る可能性もある.この可能 性については，これまで検討されたことはなかった.

したがって, 本研究では, 想定外の環境に曝された圧力容 器にどのような腐食が起りうるかを予測するため, 次の手順 で検討する．まず，現状をいかなる状態と想定するかについ て考察し, 迅速に腐食知見を得るための加速腐食試験条件の 設定について検討し，その設定条件で得られた実験結果につ いて考察する，そして，想定してないような激しい腐食が起 る可能性がないかを調べ, 圧力容器の腐食に対する保全性を 検討する.

\section{2. 現状を想定した圧力容器内のモデル化}

事故を起こした原子炉は沸騰水型原子炬であるが，一般に 知られている知見に基づいて考察する. 事故を起こした 1 , 2,3 号炉圧力容器はそれぞれ製造時も異なることから, 個 別事情は無視して取り扱う.

Fig. 1 に沸騰水型原子炉の圧力容器図を示す. 事故原子炉 の詳しい圧力容器構造図は政府報告書5)に示されている. 圧 力容器は $15 \sim 16 \mathrm{~cm}$ 厚さの低合金鋼であり, ステンレス鋼 と耐食性ニッケル基超合金で内張りされて耐食性を上げてい る. 圧力容器材料の劣化は, 同一材料で作製して圧力容器内 に挿入した監視試験片で点検されている，最も懸念されてい るのは, 中性子照射脆化と応力腐食割れで, 耐食性の内張り が損傷しない限り, 短期間における圧力容器自体の深刻な腐 食はほとんど起らない。

それに対し, 今回の事故で圧力容器は激しい損傷を受けた と思われるが，ほとんど知見は得られていない．東京電力の 解析 ${ }^{1)}$ では, 1 号炉の核燃料は圧力容器から格納容器に落下 し, 2,3 号炉の然料は圧力容器内に留まっている状況を予想
している. 圧力容器がすでに穴が空いている場合と空いてい ない場合では状況は異なるが，いずれの場合も，制御棒を溶 接した箇所などが破壊した可能性が高い。そこで，Fig. 1 （b）にそれをモデル化した図を示した．圧力容器の耐食性二 ッケル基超合金溶接部の一部が破壊し，低合金鋼が直接，溶 液に曝され，また，貫通した部分があり，低合金鋼との間で ガルバニ対になりうる状況を想定する.

溶融核然料が圧力容器底部に溜をるとすれば，圧力容器材 料がそこだけ局所的に高温, 高放射線量に曝される. そし て，事故対策として注入された海水，“小ウ酸”は高温，高 圧下で水の蒸発と共に高濃度化した恐れもある. その後は冷 温停止が図られているが，圧力容器底部に溜まっていると思 われる核然料は高放射能の発熱体でしかも圧力容器と接して いるため，その部分が特異な腐食環境であることも予想され る.

\section{3. 加速腐食実験の設定条件}

先に現状を予測して簡単にモデル化したが，現状は全くと いってよいほぼわかっていない，そこで，情報不足の状況下 で, 圧力容器の腐食の可能性をどのような実験条件で調べる べきかを考察する．想定してないような激しい腐食が起りう る可能性がないかを調べるために，加速腐食実験を行うため の実験条件を考察する．想定される材料，想定される化学物 質を使いながらも, 極端な実験条件で加速腐食試験を行う。 そして, それを起点として実験パラメータを変化させ, 圧力 容器の状況がわかり次第, 順次, 現実に即した実験条件で調 べていくという手順を取ることとする.

使用材料としては，実際の事故炉の圧力容器材料は入手で きないため, 改良された現行の圧力容器鋼 SA533Bを使用 する，また，今後，継続的に実験を続行していくためには， かえって汎用性のある材料を使用したほうがよいと判断した.
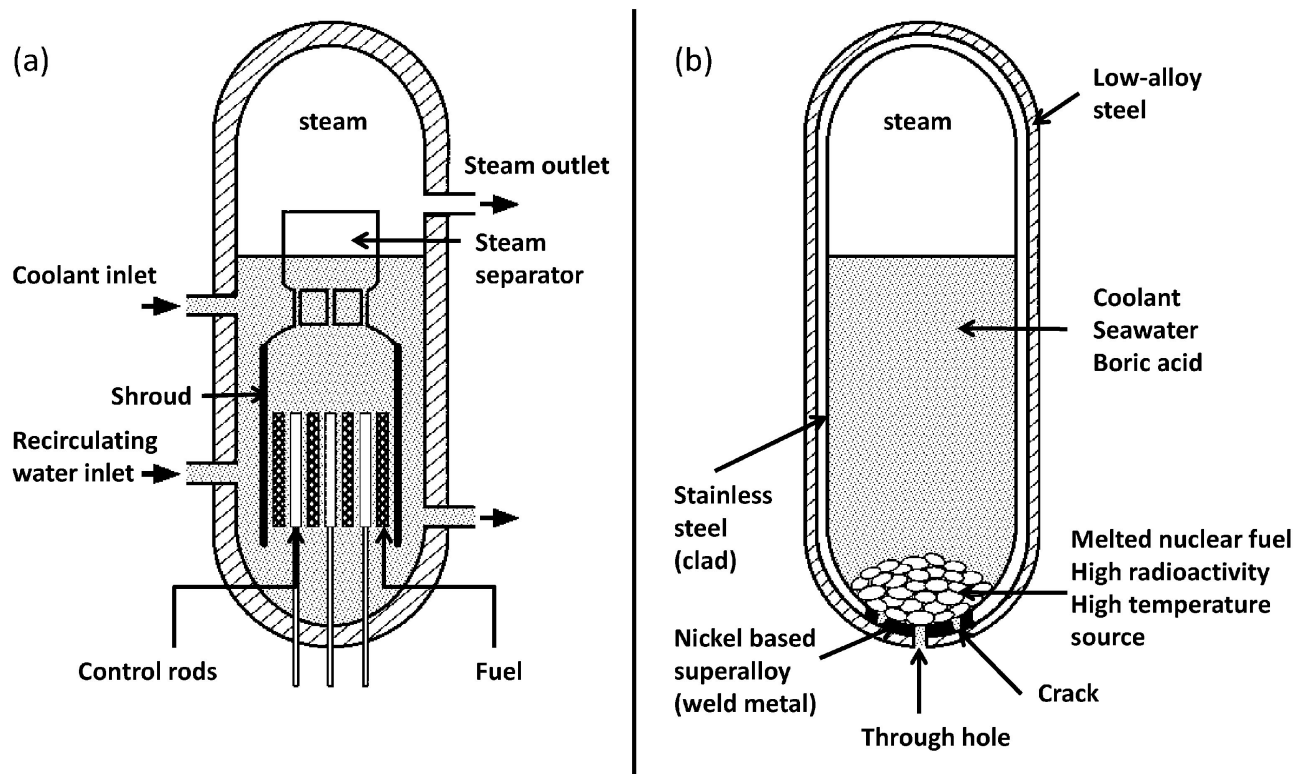

Fig. 1 Schematic diagrams of boiling water reactor pressure vessel: (a) a diagram of the usual vessel and (b) a model of the damaged vessel. 
Table 1 Chemical compositions of materials. Low alloy steel (SA533B):

\begin{tabular}{lcccccccccc}
\hline \multicolumn{1}{c}{ Element } & $\mathrm{Fe}$ & $\mathrm{C}$ & $\mathrm{Si}$ & $\mathrm{Mn}$ & $\mathrm{P}$ & $\mathrm{Cu}$ & $\mathrm{Ni}$ & $\mathrm{Cr}$ & $\mathrm{Mo}$ & $\mathrm{S}$ \\
\hline $\begin{array}{l}\text { Composition } \\
\text { (mass\%) }\end{array}$ & (Bal.) & 0.19 & 0.23 & 1.41 & 0.003 & 0.01 & 0.65 & 0.16 & 0.57 & 0.00 \\
$\begin{array}{l}\text { Fukushima } \\
\text { reactor }\end{array}$ & - & - & 0.29 & - & 0.020 & 0.23 & 0.55 & - & - & - \\
\hline
\end{tabular}

$\mathrm{Ni}-16 \mathrm{Cr}-7 \mathrm{Fe}$ alloy (Inconel 600):

\begin{tabular}{cccccccccc}
\hline Element & $\mathrm{C}$ & $\mathrm{Si}$ & $\mathrm{Mn}$ & $\mathrm{P}$ & $\mathrm{S}$ & $\mathrm{Cu}$ & $\mathrm{Ni}$ & $\mathrm{Cr}$ & $\mathrm{Fe}$ \\
\hline $\begin{array}{c}\text { Composition } \\
(\text { mass\%) }\end{array}$ & 0.04 & 0.01 & 0.24 & 0.008 & 0.001 & 0.07 & 76.05 & 15.75 & 7.02 \\
\hline
\end{tabular}

Fe: Purity $>99.99 \%$

Table 1 にその分析值を示す. 熱処理としては, $1153 \mathrm{~K}$ で $0.6 \mathrm{ks}$ 間保持後に焼き入れ，923 K で $1.8 \mathrm{ks} / 25 \mathrm{~mm}$ の割 合で $55 \mathrm{~mm}$ 厚さの鋼板を焼き戻した，参考までに，事故を 起こした福島原発 1 号炉の公表されている主要元素の組成 ${ }^{6)}$ も合わせて示す。圧力容器鋼材の改善については, 古平7)の 解説がある. 重要な変更は, 1973 年度付近を境に銅, リ ン，イオウ濃度を下げて高純度化を図ったことであるが，1 号炉はそれ以前の古い型である. 高純度化対策は, 主として 中性子照射脆化と応力腐食割れを防ぐためのもので，たとえ

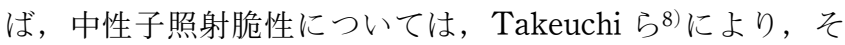
の影響が調べられている，腐食性の観点からも，含有する銅 は局部カソードになって低合金鋼内でガルバニ腐食を起しう

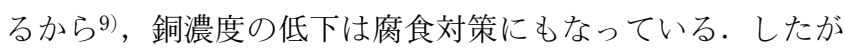
って, 現行材料を用いると, 事故圧力材料よりは耐食性がよ いことは承知しておく必要があるが，後に実験結果で示すよ うに，現行材料ですでに激しい腐食が起る.

腐食性の評価のための比較材料は純鉄とする. 現行の SA 533B といえども特殊材料で簡単に入手できないため, 鉄で 実験すればどのような違いがあるかを調べることも重要と考 えたためである.内張り材料はステンレス鋼, 溶接材料は耐 食性ニッケル基超合金であり，内張りのステンレス鋼部分が 破損する可能性も無視できないが，本研究では制御棒の継ぎ 目である耐食性ニッケル基超合金の箇所で亀裂が生じて破断 する可能性が最も高いと推測し，試験材料としては実際に使 われて汎用性の高いインコネル 600 相当の材料を選んだ.

Table 1 に示した主要元素の組成から本研究で使用した材料 を $\mathrm{Ni}-16 \mathrm{Cr}-7 \mathrm{Fe}$ と表記する，原子炬材料として使用された インコネル 600 の破損例は数々知られて抢り, 文献 10)では その考察がなされている。

事故対策初期には冷却用に海水が注入された。 また, 事故 初期に再臨界防止のため, “小ウ酸” が注入され，その後も 時々注入されている. 通常は, 加圧水型原子炬では酸性の木 ウ酸 $\mathrm{H}_{3} \mathrm{BO}_{3}$, 沸騰水型原子炬ではアルカリ性の五ホウ酸ナ トリウム $\mathrm{NaB}_{5} \mathrm{O}_{8} \cdot 5 \mathrm{H}_{2} \mathrm{O}$ が注入されることになっているが， 緊急事態でどのような組成のものが注入されたかは不明であ る、いずれにしろ，五ホウ酸ナトリウム $\mathrm{NaB}_{5} \mathrm{O}_{8} \cdot 5 \mathrm{H}_{2} \mathrm{O}$ がボ ラックス $\mathrm{Na}_{2} \mathrm{~B}_{4} \mathrm{O}_{7} \cdot 10 \mathrm{H}_{2} \mathrm{O}$ とホウ酸 $\mathrm{H}_{3} \mathrm{BO}_{3}$ の混合物であ り, 注入された海水の主成分が約 $3 \mathrm{mass} \%$ 濃度の $\mathrm{NaCl}$ 水 溶液であることを考慮すると, 圧力容器環境の主たる溶液組 成は, $\mathrm{NaCl}-\mathrm{H}_{3} \mathrm{BO}_{3}-\mathrm{Na}_{2} \mathrm{~B}_{4} \mathrm{O}_{7}$ 系と考えられる. 5 ホウ酸ナト
Table 2 Chemical compositions of solutions. ${ }^{* 1}$

\begin{tabular}{lccc}
\hline & $\mathrm{NaCl}$ & $\mathrm{H}_{3} \mathrm{BO}_{3}$ & $\mathrm{H}_{2} \mathrm{O}$ \\
\hline $\begin{array}{l}\text { Amount } \\
\text { Maximum }\end{array}$ & $20.00 \mathrm{~g}$ & $20.00 \mathrm{~g}$ & $25.00 \mathrm{~g}$ \\
\hline $13.7 \mathrm{~mol} / \mathrm{kg}$ & $12.9 \mathrm{~mol} / \mathrm{kg}$ & \\
\hline $373 \mathrm{~K}$ & $\begin{array}{c}7.23 \mathrm{~mol} / \mathrm{kg} \\
\text { (Saturated concentration) }\end{array}$ & $\begin{array}{c}6.71 \mathrm{~mol} / \mathrm{kg} \\
6.14 \mathrm{~mol} / \mathrm{kg}\end{array}$ \\
$298 \mathrm{~K}$ & $\begin{array}{c}\text { (Saturated concentration) } \\
0.93 \mathrm{~mol} / \mathrm{kg}\end{array}$ & \\
(Saturated concentration) & (Saturated concentration) & \\
\hline
\end{tabular}

${ }^{* 1}$ Three solutions with the same amount of $\mathrm{H}_{2} \mathrm{O}$ were prepared: $20.00 \mathrm{~g}$ $\mathrm{NaCl}$ and $20.00 \mathrm{~g} \mathrm{H}_{3} \mathrm{BO}_{3}$ in $25.00 \mathrm{~g} \mathrm{H}_{2} \mathrm{O}$ (as a $\mathrm{NaCl}-\mathrm{H}_{3} \mathrm{BO}_{3}$ solution); $20.00 \mathrm{~g} \mathrm{NaCl}$, in $25.00 \mathrm{~g} \mathrm{H}_{2} \mathrm{O}$ (as a NaCl solution); $20.00 \mathrm{~g} \mathrm{H}_{3} \mathrm{BO}_{3}$ in 25.00 g $\mathrm{H}_{2} \mathrm{O}$ (as a $\mathrm{H}_{3} \mathrm{BO}_{3}$ solution).

*2 At $423 \mathrm{~K}$, the maximum concentration $(12.9 \mathrm{~mol} / \mathrm{kg})$ of $\mathrm{H}_{3} \mathrm{BO}_{3}$ is lower than the saturated concentration $(19.4 \mathrm{~mol} / \mathrm{kg})$.

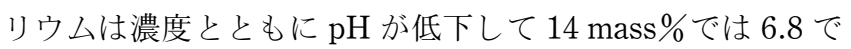
あるから ${ }^{11)}$, 溶液が濃縮される状況では, ほぼ中性であ る. 溶融したウラン燃料から生じた $\mathrm{UO}_{2}{ }^{2+}$ イオンは $\mathrm{UO}_{2}{ }^{2+}$ $+\mathrm{H}_{2} \mathrm{O}=\mathrm{UO}_{3}+2 \mathrm{H}^{+}$で水素イオンを発生しうる.いずれに しても, 事故圧力容器内で安定な溶液組成を保持することは 難しく, pH 変動は起りうるから, 本研究では酸性側に極端 に移行する場合を想定して溶液系を $\mathrm{NaCl}-\mathrm{H}_{3} \mathrm{BO}_{3}$ 系に設定 する。

温度は $423 \mathrm{~K}$ に設定する. この根拠は, 次の 2 つの理由 の兼ね合いによる. 東京電力の報告書1)によれば, 格納容器 内の圧力容器外側に設置した温度計で計測すると, $1,2,3$ 号炉はいずれも事故直後は $473 \mathrm{~K}$ 以上の高温が続き, 事故 後約 2 カ月経っても $373 \mathrm{~K}$ 以上の高温であった。ただし， 文献 4)によれば，SA533B を用いて $298 \mathrm{~K}$ で飽和にした $\mathrm{H}_{3} \mathrm{BO}_{3}$ 水溶液でその腐食量を調べると, $423 \mathrm{~K}$ を越えると かえって腐食量が減少するという現象が観察された。 そこで, $423 \mathrm{~K}$ 以上で実験してもより加速腐食実験をしたことになら ないと判断して，423 K に設定した. 比較のため， $298 \mathrm{~K}$ と $373 \mathrm{~K}$ における実験も行った.

試験溶液は, $\mathrm{NaCl}-\mathrm{H}_{3} \mathrm{BO}_{3}$ 水溶液を基本とし, 単独 $\mathrm{NaCl}$ 水溶液, 単独 $\mathrm{H}_{3} \mathrm{BO}_{3}$ 水溶液を比較のために使用した.

Table 2 に, 具体的な溶液組成を質量モル濃度で示す. 溶液 調整は, 混合, 単独水溶液ともに表中に示した成分質量を秤 量した. いずれの場合も使用水分量は $25.00 \mathrm{~g}$ に固定し, 混 合水溶液中の $\mathrm{NaCl}, \mathrm{H}_{3} \mathrm{BO}_{3}$ 量は単独水溶液の時と同量にし た.ここで示した飽和水溶液の溶解度は文献值から求めた $\mathrm{NaCl}^{12)}$ と $\mathrm{H}_{3} \mathrm{BO}_{3}{ }^{13)}$ の個々の溶解度であり, 混合水溶液中 の相互溶解度に関する知見は十分でないため, その影響は示 していない. 原子炉圧力容器は高温下, 冷却不十分であった ことを想定し, $\mathrm{NaCl}$ 水溶液についてはいずれの温度につい ても飽和水溶液になるように過剰に添加した. $\mathrm{H}_{3} \mathrm{BO}_{3}$ につ いては, $373 \mathrm{~K}$ 以下では飽和水溶液にしたが， $423 \mathrm{~K}$ では所 定の濃厚水溶液になるようにした $\mathrm{H}_{3} \mathrm{BO}_{3}$ の高温における 溶解度は大きく, $423 \mathrm{~K}$ の飽和水溶液では極端に溶媒和水の 少ない状態になるため, 水溶液腐食を知るのにかえって不適 切であると考えてあえて飽和水溶液にはしなかった。 また, 文献 4)によれば，水がないとかえって腐食しにくくなると 
いう知見が得られていることも考慮して判断した。 この混合 水溶液の $\mathrm{pH}$ は $298 \mathrm{~K}$ で 3.23 であった. Table 2 には, 混 合水溶液にした場合の相互溶解度の効果は考慮していないが, 303 373 K で NaCl- $\mathrm{H}_{3} \mathrm{BO}_{3}$ 混合水溶液の相互溶解度を測定 した結果によれば14)，373 K で $\mathrm{NaCl}$ 飽和濃度は $7.149 \mathrm{~mol} /$ $\mathrm{kg}, \mathrm{H}_{3} \mathrm{BO}_{3}$ 飽和濃度は $6.797 \mathrm{~mol} / \mathrm{kg}$ で, 単独の場合よりも 溶解度が増す。このため, $423 \mathrm{~K}$ においても, $\mathrm{NaCl}$ の溶解 度は単独溶液の場合より大きく腐食性も増すと予想される.

核然料からの放射線の影響は当然, 調べるべきことではあ るが，通常の実験環境でそのような高放射性物質は扱えない ために，材料の放射線損傷の効果は無視する。ただし，核燃 料が圧力容器底部に溜まるとすれば，その部分での水の放射 線分解による高濃度の水素, 酸素, 過酸化水素の発生が起り うる. 酸素の発生については, その状態を酸素加圧で模擬す る.

\section{4. 実 験 方 法}

実験装置は, 著者ら ${ }^{15)}$ が高温, 高圧下で $\mathrm{Fe}-\mathrm{Zn}$ ガルバニ 腐食研究に用いたものを使い, 実験方法も特に断らない限り 同様とした.

試料は, 長さ $3.5 \mathrm{~cm}$, 幅 $1 \mathrm{~cm}$ で所定厚さに切断後, 800 番までの耐水エメリーペーパーで研磨し, アセトンで洗浄し た. 試料と同一材料で作製したリード棒にアクリルねじで止 めて装置に取り付けた．試料は両面の $1 \mathrm{~cm} \times 2 \mathrm{~cm} の$ 面積だ けを露出させて, その他の部分をテフロンテープで被覆し た. 実験後も, テフロンテープの部分は全く腐食しておら ず，完全に溶液から絶縁されていることを確認した.

オートクレーブ内で内容積 $70 \mathrm{~mL}$ の耐熱ガラス容器に入 れた調合試薬に試料を浸すようにオートクレーブを組み立て た。試料を溶液に入れる時には, 試料下部は $\mathrm{NaCl}$ と $\mathrm{H}_{3} \mathrm{BO}_{3}$ が沈殿しているところまで浸したが, 取り出した試料の腐食 にはその影響は見られなかった. チッ素で脱気しながら昇温 し， $363 \mathrm{~K}$ に達した時，一度ガスを止め，オートクレーブの ガスの出入り口を閉じた. $373 \mathrm{~K}$ に達した時, 再度ガスの出 口を一時的に開放してチッ素を追い出し, 水蒸気のみの䨌囲

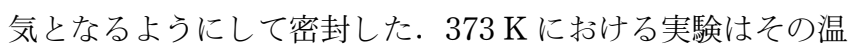
度に保持して行った. $423 \mathrm{~K}$ の実験では，その後に $423 \mathrm{~K}$ まで加温したが, 室温からの昇降温には約 $1.2 \mathrm{ks}$ 要した. また， $423 \mathrm{~K} て ゙ ~ 2 \mathrm{MPa}$ 酸素加圧の実験を行ったが，断熱加 圧による急激な温度上昇を避けるために, $393 \mathrm{~K} に$ 達した時 に酸素ガスを $1.7 \mathrm{MPa}$ 程度導入し， $423 \mathrm{~K}$ に達した時に 2 $\mathrm{MPa}$ になるように調整して測定を開始した.

電気化学的測定としては, 自然浸漬電位測定, 分極曲線測 定, ガルバニ電流, 電位測定などを行い, 取り出した試料に ついては, 光学顕微鏡で表面観察, EPMA で試料断面観察 を行った，電位測定の照合電極には, $\mathrm{KCl}$ 飽和の $\mathrm{Ag} / \mathrm{AgCl}$ 電極を用いた.

\section{5. 実 験 結 果}

特に記載のないものは， 3 で決定した基準となる実験条
件, すなわち, $423 \mathrm{~K}$, 飽和 $\mathrm{NaCl}$-濃厚 $\mathrm{H}_{3} \mathrm{BO}_{3}$ 混合水溶液 で $14.4 \mathrm{ks}(4 \mathrm{~h})$ 測定して得られた実験結果である.

Fig. 2 に, 使用した材料, Fe, SA533B, Ni-16Cr-7Fe 合 金の自然浸漬電位を示す. $10 \mathrm{ks}$ 程度の時間までは測定電位 は安定で, $\mathrm{Ni}-16 \mathrm{Cr}-7 \mathrm{Fe}$ 合金は約 $-0.30 \mathrm{~V}, \mathrm{SA} 533 \mathrm{~B}$ は約 $-0.45 \mathrm{~V}$, 純 Fe は約-0.55 Vであった。したがって, 電位 は $\mathrm{Ni}-16 \mathrm{Cr}-7 \mathrm{Fe}$ 合金が最も高く, Fe が最も低いから, Fe と SA533B は Ni-16Cr-7Fe 合金に対しアノードとなり，対 にするとガルバニ腐食が進行すると予想される. その電位差 の大きさからは, Fe のほうが SA533B よりも激しいガルバ 二腐食になると予想される. なお, 時間が経過すると Ni$16 \mathrm{Cr}-7 \mathrm{Fe}$ 合金の電位は不安定になった。 また, Fe の電位 が上昇して， $\mathrm{Ni}-16 \mathrm{Cr}-7 \mathrm{Fe}$ 合金と電位逆転が起りうるよう になった。本研究では, 腐食初期の実験結果に着目してお り，まだ腐食の長期時間依存性については詳しく検討してい ないが，約 $14.4 \mathrm{ks}$ を過ぎると，実際に $\mathrm{Fe} / \mathrm{Ni}-16 \mathrm{Cr}-7 \mathrm{Fe}$ 合 金，また， SA533B/ Ni-16Cr-7Fe 合金でも電位逆転現象が 起ることを確認した.

Fig. 3 には, SA533B と Ni-16Cr-7Fe 合金の分極曲線の 例を示す。両試料, 特に $\mathrm{Ni}-16 \mathrm{Cr}-7 \mathrm{Fe}$ 合金の実験の再現性 は悪かった。この溶液は実験中には $\mathrm{pH} 3 \sim 4$ の範囲の弱酸

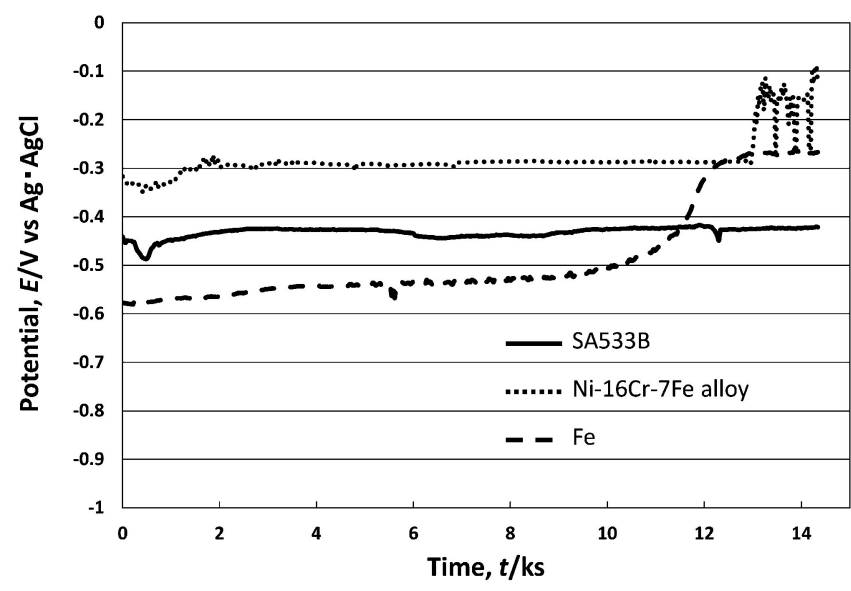

Fig. 2 Open-circuit potentials for SA533B, Ni-16Cr-7Fe alloy and Fe.

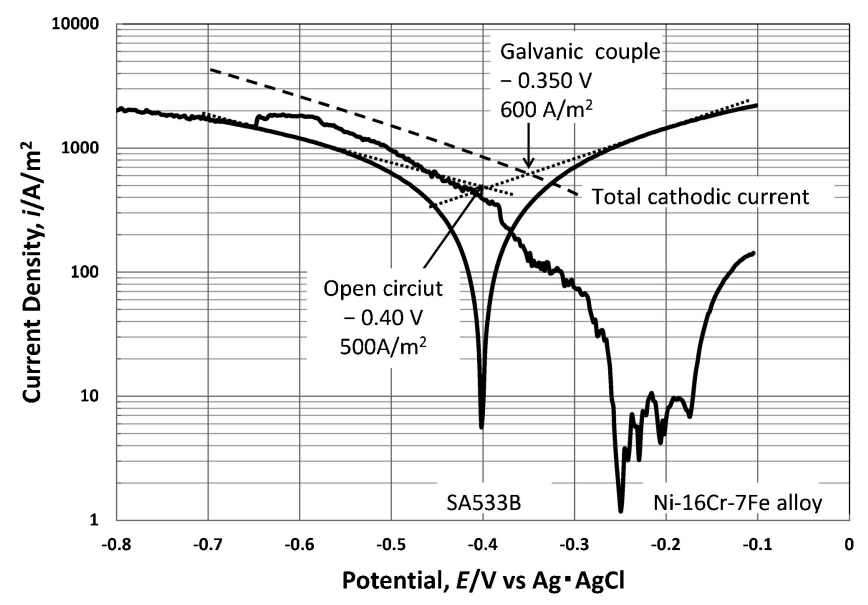

Fig. 3 Polarization curves obtained at a sweep rate of $0.5 \mathrm{mV} / \mathrm{s}$ for SA533B and $\mathrm{Ni}-16 \mathrm{Cr}-7 \mathrm{Fe}$ alloy. 
性溶液であった，したがって，SA533B のカソード反応は水 素の発生と溶存酸素の還元，アノード反応は主成分の Fe の 溶解と考えられる. 反応機構については後に考察する. $\mathrm{Ni}-$ $16 \mathrm{Cr}-7 \mathrm{Fe}$ 合金上のカソード反応も SA533B 上と同様の反応 と考えられる. SA533Bのアノード，カソード分極曲線を外 挿して得られる腐食電流密度は約 $500 \mathrm{~A} / \mathrm{m}^{2}$ で, 換算した腐 食速度は $0.07 \mathrm{~mm} / \mathrm{h}$ である. またガルバニ対にした場合， $\mathrm{SA} 533 \mathrm{~B}$ と $\mathrm{Ni}-16 \mathrm{Cr}-7 \mathrm{Fe}$ 合金の電位差は $200 \mathrm{mV}$ 以下であ るから， $\mathrm{Ni}-16 \mathrm{Cr}-7 \mathrm{Fe}$ 合金上のカソード電流は無視できな く, SA533B のアノード電流が SA533B のカソード電流と $\mathrm{Ni}-16 \mathrm{Cr}-7 \mathrm{Fe}$ 合金のカソード電流の和であるとして補正す ると，腐食電流密度は約 $600 \mathrm{~A} / \mathrm{m}^{2}$ で，換算した腐食速度は $0.08 \mathrm{~mm} / \mathrm{h}$ である.ガルバニ腐食の寄与は $100 \mathrm{~A} / \mathrm{m}^{2}$ であ る.すなわち，SA533B それ自体の腐食が激しいが，ガルバ 二対になるとさらに加速される。ただし，SA533B と Ni$16 \mathrm{Cr}-7 \mathrm{Fe}$ 合金のいずれも分極曲線測定の再現性が悪く，ま た，アノード，カソード分極曲線の外挿の仕方にも任意性が あるから，得られた值は概略值である.

Fig. 4 に，実際に SA533B 試料片の先端に礼じを切って $\mathrm{Ni}-16 \mathrm{Cr}-7 \mathrm{Fe}$ 合金試料片にねじ込んで内部ガルバニ対にし た試料を溶液に浸漬した場合の $14.4 \mathrm{ks}$ 後の観察結果を示す. SA533B は著しく腐食し, 腐食生成物の密着性は悪い. $\mathrm{SA} 533 \mathrm{~B} / \mathrm{Ni}-16 \mathrm{Cr}-7 \mathrm{Fe}$ 合金境界部分を拡大観察すると，界 面が凸凹して扣り，SA533B のみならず， Ni-16Cr-7Fe 合 金も腐食してかみ合っているように見える. 左右の断面の減 肉量から腐食速度を求めると, $0.066 \mathrm{~mm} / \mathrm{h}$ であった。この 断面観察結果からはガルバニ腐食の有無は不明である。ただ し，実用のインコネル 600 は耐食性がよいが，隙間腐食を 起こすことがよく知られている10).このガルバニ対でより 長時間観察すれば，隙間腐食の有無を明らかにすることがで きると思われる.

各種実験パラメータを変化させた場合のガルバニ腐食への 影響を調べたが，その結果を Fig. 5 から Fig. 8 に示す.

Fig. 5 に，ガルバニ対の組み合わせによる比較を示す. $\mathrm{Fe} / \mathrm{Ni}-16 \mathrm{Cr}-7 \mathrm{Fe}$ 合金と SA533B/Ni-16Cr-7Fe 合金でガル
バニ電流を比較すると， $\mathrm{Fe} / \mathrm{Ni}-16 \mathrm{Cr}-7 \mathrm{Fe}$ 合金のほうが著し く大きい。これは，Fig. 2 で示した自然浸漬電位測定から得 られたガルバニ対の電位差の大きさの違いに対応している.

SA533B/Ni-16Cr-7Fe 合金では時間が経過するとガルバニ 電流がほとんど流れなくなるが，結線直後は $40 \mathrm{~A} / \mathrm{m}^{2}$ 程度 で， $14.4 \mathrm{ks}$ の平均は $5 \mathrm{~A} / \mathrm{m}^{2}$ 程度で，換算すると 0.0007 $\mathrm{mm} / \mathrm{h}$ である。これに対し， $\mathrm{Fe} / \mathrm{Ni}-16 \mathrm{Cr}-7 \mathrm{Fe}$ 合金では結線 直後は $200 \mathrm{~A} / \mathrm{m}^{2}$ 程度で, 時間を経過しても $30 \mathrm{~A} / \mathrm{m}^{2}$ 程度 の一定のガルバニ電流が持続した．この場合， $30 \mathrm{~A} / \mathrm{m}^{2}$ は 換算すると， $0.004 \mathrm{~mm} / \mathrm{h}(3.4 \mathrm{~cm} / \mathrm{y})$ の腐食速度になるか ら，ガルバニ腐食の寄与も大きい。

Fig. 6 に，SA533B / Ni-16Cr-7Fe 合金対のガルバニ電 流, 電位の溶液依存性を示す. $\mathrm{NaCl}$ 水溶液, $\mathrm{H}_{3} \mathrm{BO}_{3}$ 水溶液, $\mathrm{NaCl}-\mathrm{H}_{3} \mathrm{BO}_{3}$ 混合水溶液の結果を比較すると, $\mathrm{NaCl}$ 水溶液 中では $0.04 \mathrm{~A} / \mathrm{m}^{2}$ 程度の微弱な電流しか流れず, $\mathrm{H}_{3} \mathrm{BO}_{3}$ 水 溶液中では平均すると $1 \mathrm{~A} / \mathrm{m}^{2}$ 程度のガルバニ電流が流れ, 混合水溶液中では $5 \mathrm{~A} / \mathrm{m}^{2}$ で約 5 倍である。この理由につい ては，後に検討する．なお，測定時間内では，電位はいずれ の溶液でもほぼ定常であった. $\mathrm{NaCl}-\mathrm{H}_{3} \mathrm{BO}_{3}$ 混合水溶液中の

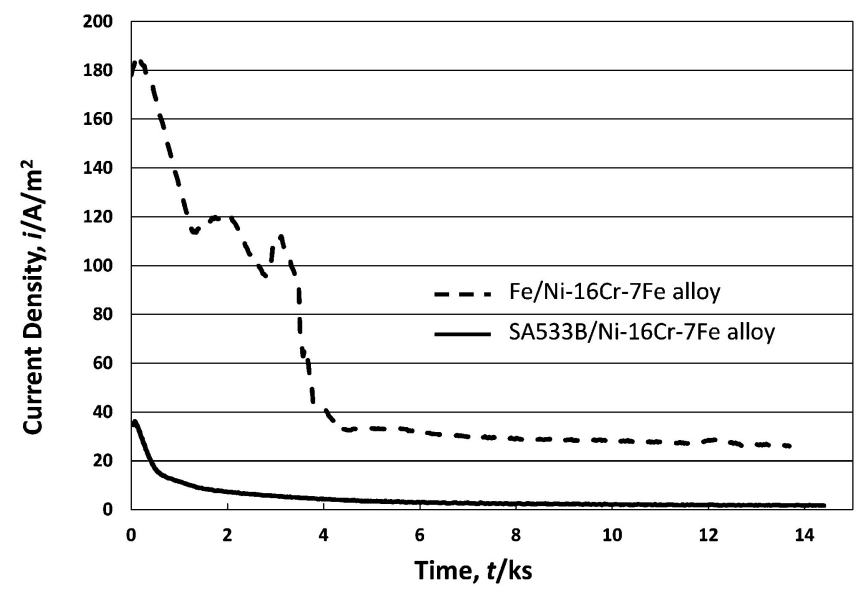

Fig. 5 Ggalvanic current densities for SA533B/Ni-16Cr-7Fe alloy and $\mathrm{Fe} / \mathrm{Ni}-16 \mathrm{Cr}-7 \mathrm{Fe}$ alloy couples.

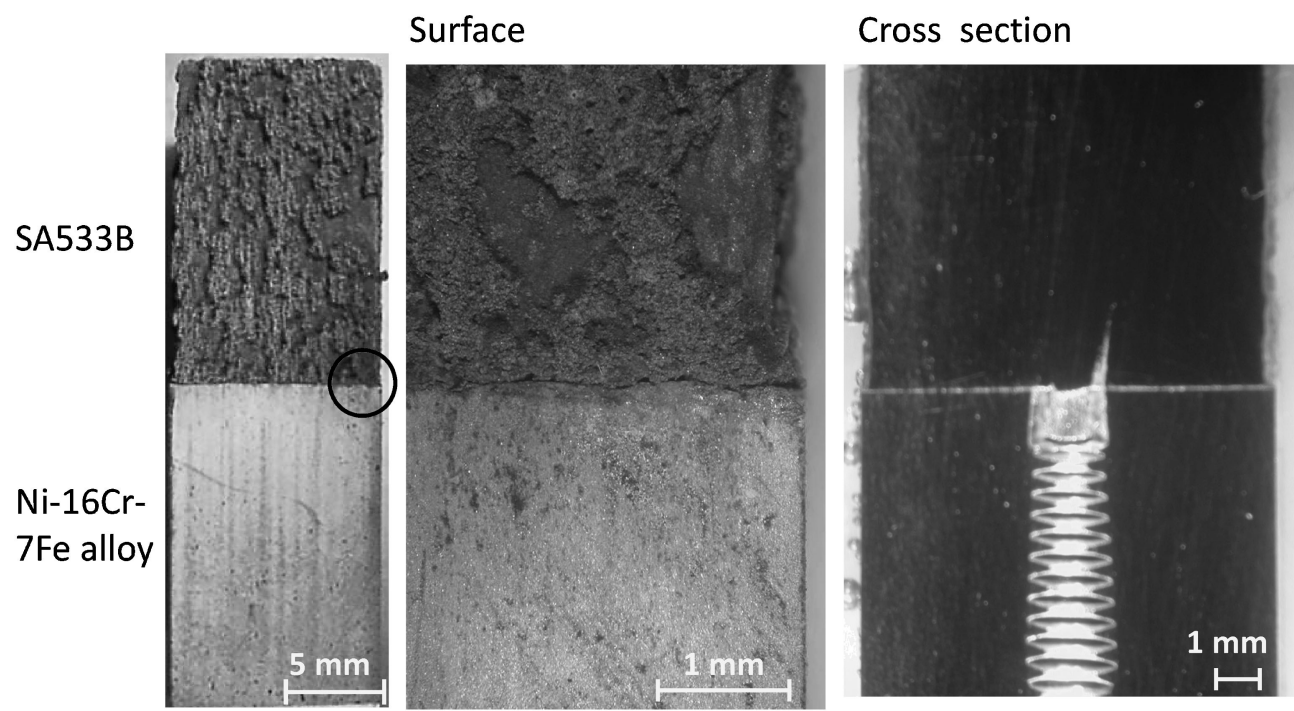

Fig. 4 Surface morphology of an internal galvanic couple. 


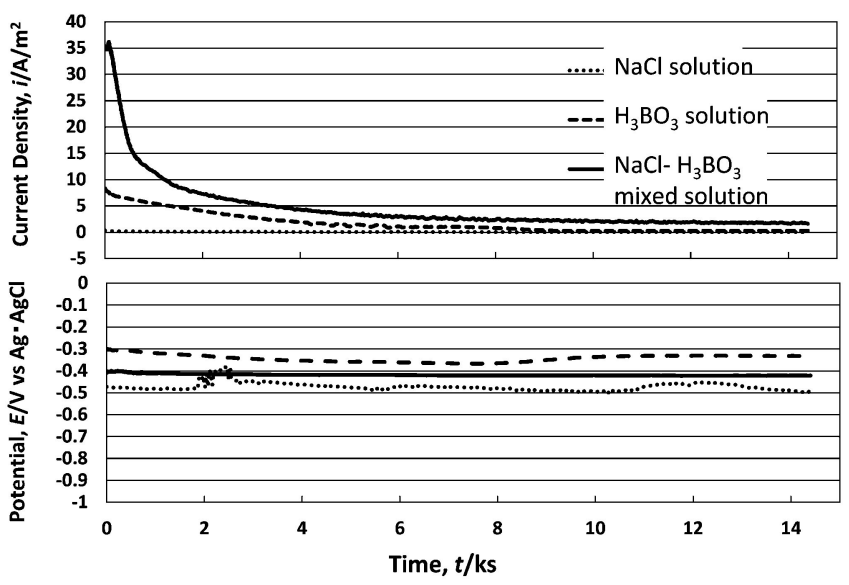

Fig. 6 Dependence of galvanic current density and galvanic potential on chemical composition of solutions for a SA533B/ $\mathrm{Ni}-16 \mathrm{Cr}-7 \mathrm{Fe}$ alloy couple.

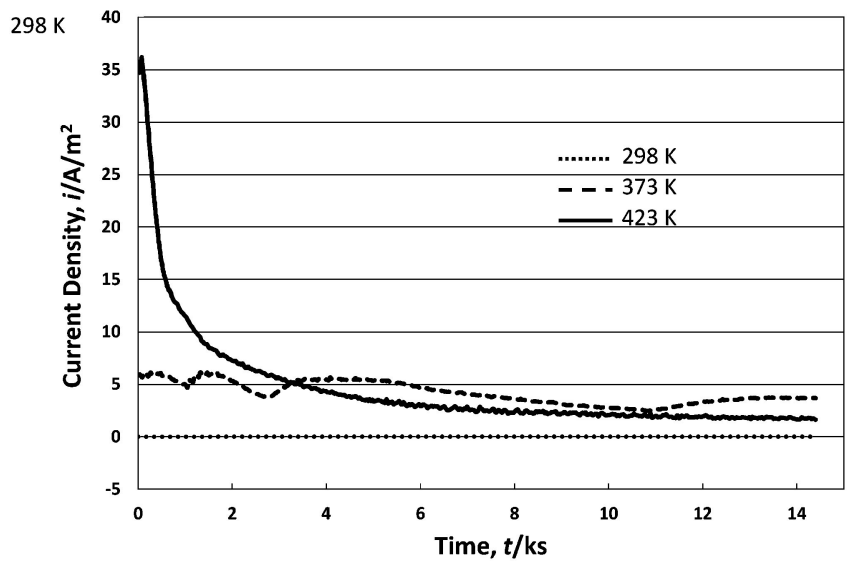

Fig. 7 Dependence of galvanic current density on temperature for a SA533B/Ni-16Cr-7Fe alloy couple.
場合，ガルバニ対にしても SA533B の自然電位からせいぜ い20 $\mathrm{mV}$ 程度しかアノード分極しないから，カソード支配 型の腐食になる。な扮，Fig. 3 に打いて点線で示した SA533Bのアノード分極曲線で自然電極電位から $20 \mathrm{mV}$ ア ノード分極した電流密度を読み取ると $30 \mathrm{~A} / \mathrm{m}^{2}$ となり，結 線直後の実測值とよく対応した。

Fig. 7 には，腐食電流の温度依存性を示す. $373 \mathrm{~K}$ でもか なりの電流が流れてガルバ二腐食が持続する。したがって, $423 \mathrm{~K}$ から $373 \mathrm{~K}$ に温度低下すると腐食性は低下するが, 腐食が著しいわけではない。文献 4)によると, $\mathrm{H}_{3} \mathrm{BO}_{3}$ 水溶 液中の自然浸漬実験では, $373 \mathrm{~K}$ から $423 \mathrm{~K}$ の範囲で腐食 性はあまり変わらない. $298 \mathrm{~K}$ では, $0.01 \mathrm{~A} / \mathrm{m}^{2}$ 程度の微弱 な電流しか流れず，ガルバニ腐食はほとんど起らない.

Fig. 8 に，酸素加圧の影響を示す. $2 \mathrm{MPa}$ に酸素加圧す

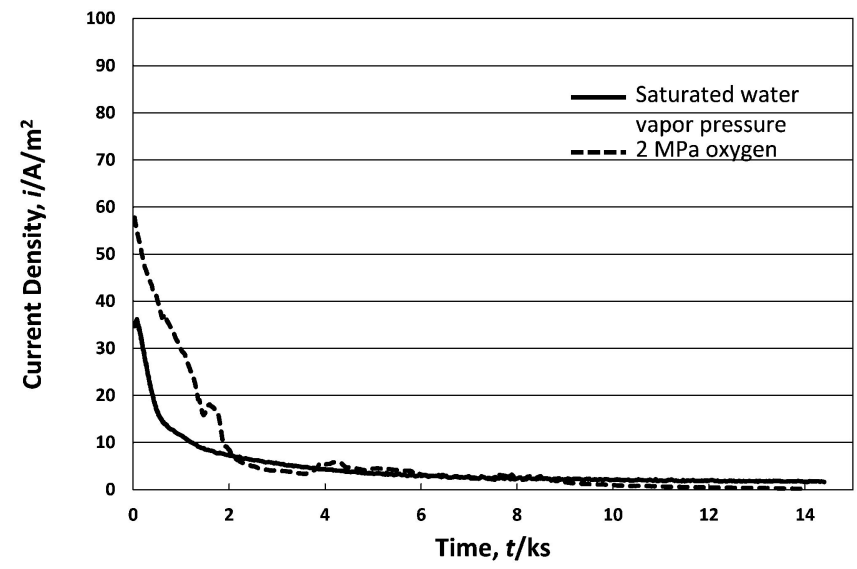

Fig. 8 Dependence of galvanic current density on atmospheric gas composition for a SA533B/ $\mathrm{Ni}-16 \mathrm{Cr}-7 \mathrm{Fe}$ alloy couple.

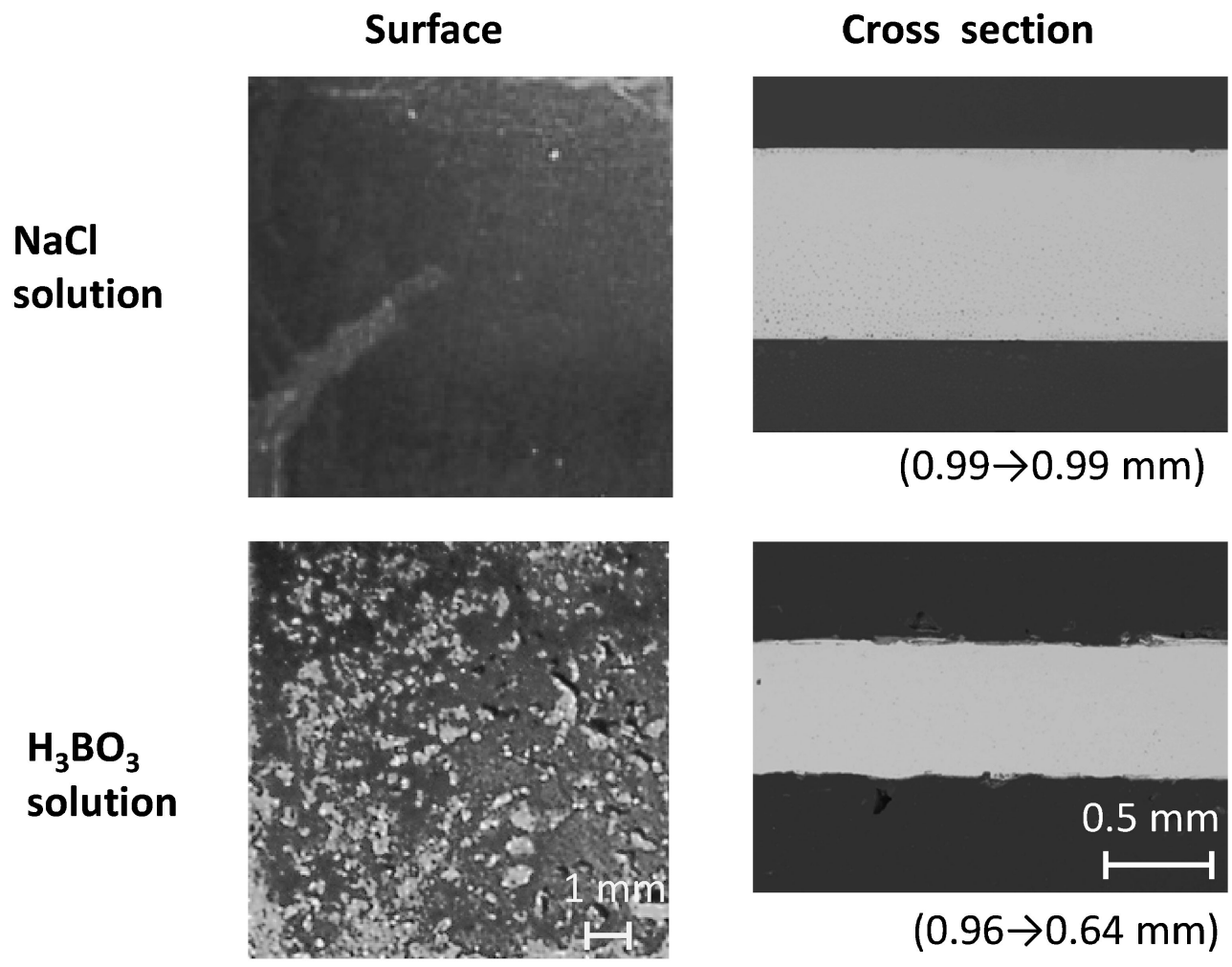

Fig. 9 Surface morphologies of SA533B in $\mathrm{NaCl}$ and $\mathrm{H}_{3} \mathrm{BO}_{3}$ solutions after 14.4 ks immersion. 
ると，ガルバニ電流は増加するが，脱気の場合と比べて結線 直後にせいぜい 2 倍程度である。したがって，この場合， 水素発生の寄与と比べ，酸化剂としての酸素の寄与はあまり 大きくない.

Fig. 9 に, $\mathrm{NaCl}$ 水溶液と $\mathrm{H}_{3} \mathrm{BO}_{3}$ 水溶液に自然浸漬した場 合の実験後の試料観察結果を示す. $\mathrm{NaCl}$ 水溶液では試料断 面は平滑でほとんど腐食していない. $\mathrm{H}_{3} \mathrm{BO}_{3}$ 水溶液では表 面に腐食生成物が見られ，断面観察からは界面がささくれ立 ったように層状にはがれていて凹凸になっていた，界面付近 を拡大観察すると, 母金属の表面から $10 \mu \mathrm{m}$ 程度内側に層 状に筋が見られ, 内部酸化が起っていると思われる. 減肉量 から得られる腐食速度は, $0.040 \mathrm{~mm} / \mathrm{h}(35 \mathrm{~cm} / \mathrm{y})$ の激しい 腐食である. 文献 4)によれば，濃度は示されていないが， 高濃度 $\mathrm{H}_{3} \mathrm{BO}_{3}$ 水溶液中, $423 \mathrm{~K}, 162 \mathrm{ks}$ の腐食試験では, $14.463 \mathrm{~cm} / \mathrm{y}$ の腐食速度である. 本研究の結果より腐食速度 が小さいのはより長時間の平均值であるためと思われる.

Fig. 10 には $\mathrm{NaCl}-\mathrm{H}_{3} \mathrm{BO}_{3}$ 混合水溶液で, 自然浸漬あるい はガルバニ対実験後の試料を取り出して観察した結果を示す. $\mathrm{NaCl}-\mathrm{H}_{3} \mathrm{BO}_{3}$ 混合水溶液では, $\mathrm{H}_{3} \mathrm{BO}_{3}$ 水溶液中よりもさら に激しく腐食し, 腐食生成物は多孔質で, 密着性は悪く, 手 で触ると簡単に取れてしまった。 外見からは，ガルバニ試料 のほうがより多孔質であった。断面観察結果から，激しく腐 食し，界面が凸凹になっていたが，ガルバニ試料のほうが凹 凸が激しかった. 断面観察結果から求めた腐食速度は, 自然 浸漬試料で $0.065 \mathrm{~mm} / \mathrm{h}$ ，ガルバニ実験試料で $0.075 \mathrm{~mm} / \mathrm{h}$ であった，ただし，このように凸凹のある試料では破損速度 を知るという観点からは最も凹んだ厚さが問題となるから， その時の腐食速度を測定すると，ガルバニ実験試料で 0.082 $\mathrm{mm} / \mathrm{h}$ であった.

Table 3 に, Fig. 4, Fig. 9, Fig. 10 の断面観察から得られ た腐食速度を比較して示す。 また, $\mathrm{NaCl}-\mathrm{H}_{3} \mathrm{BO}_{3}$ 混合水溶液 については, Fig. 3 の分極測定から得られた值も示す. 分極 測定から算出された值と試料観察結果から得られた值はよく 合っている.ただ, 分極測定結果は算出法にも依存し, 概 略值である. 断面測定した結果は直接の実測值であるから信 頼性が高いが，測定誤差を考慮すれば，減肉量におよぼすガ ルバニ腐食の効果はまだ明確ではない.Fig. 5 で示したよう に, 実測のガルバニ電流密度の平均值は $5 \mathrm{~A} / \mathrm{m}^{2}$ で, 0.0006 $\mathrm{mm} / \mathrm{h}$ にしかならないから測定䛊差範囲であるが, 結線直 後は約 $40 \mathrm{~A} / \mathrm{m}^{2}$ で $0.005 \mathrm{~mm} / \mathrm{h}$ の寄与となる. 測定誤差を 考慮して得られる $\mathrm{NaCl}-\mathrm{H}_{3} \mathrm{BO}_{3}$ 混合水溶液中の腐食速度 は，自然浸漬，ガルバニ対を含めて $0.07 〜 0.08 \mathrm{~mm} / \mathrm{h}(60 \sim$ $70 \mathrm{~cm} / \mathrm{y}$ )である.

Table 3 Calculated corrosion rates of SA533B at $423 \mathrm{~K}$.

\begin{tabular}{cccc}
\hline $\mathrm{NaCl}$ & $\mathrm{H}_{3} \mathrm{BO}_{3}$ & & $\mathrm{NaCl}-\mathrm{H}_{3} \mathrm{BO}_{3}$ \\
\hline Not coupled & Not coupled & Not coupled & $\begin{array}{c}\text { Coupled with } \\
\text { nickel based superalloy }\end{array}$ \\
\hline Not detected & $\begin{array}{c}0.040 \mathrm{~mm} / \mathrm{h} \\
(35 \mathrm{~cm} / \mathrm{y})\end{array}$ & $\begin{array}{c}0.065 \mathrm{~mm} / \mathrm{h} \\
(57 \mathrm{~cm} / \mathrm{y})\end{array}$ & $\begin{array}{c}0.075 \mathrm{~mm} / \mathrm{h}(\text { External }) \\
(66 \mathrm{~cm} / \mathrm{y})\end{array}$ \\
& & $0.066 \mathrm{~mm} / \mathrm{h}($ Internal $)$ \\
& & $0.07 \mathrm{~mm} / \mathrm{h}^{*}$ & $0.08 \mathrm{~cm} / \mathrm{ym})$ \\
& & $(60 \mathrm{~cm} / \mathrm{y})$ & $(70 \mathrm{~cm} / \mathrm{y})$ \\
\hline
\end{tabular}

* From the polarization analyses (see Fig. 3)

\section{Surface}
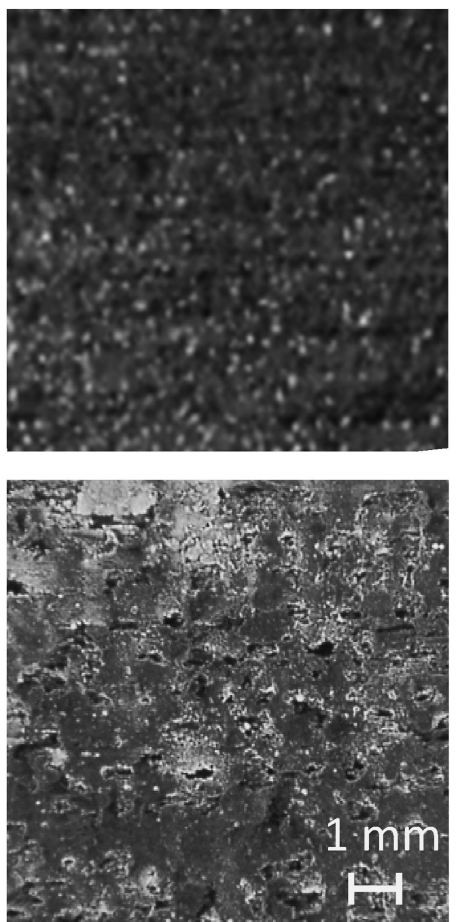

Cross section

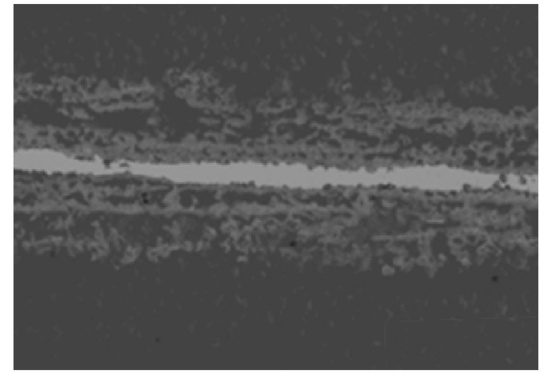

$(0.60 \rightarrow 0.08 \mathrm{~mm})$

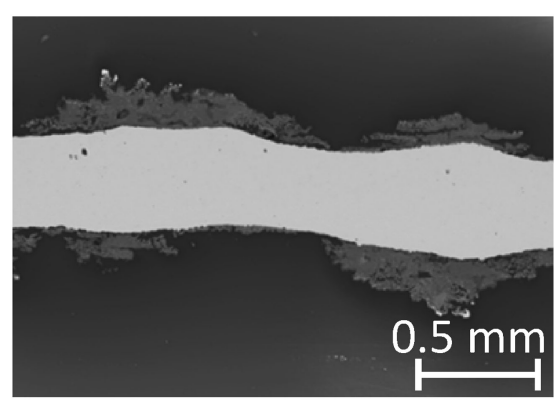

$(1.00 \rightarrow 0.40 \mathrm{~mm})$

Fig. 10 Surface morphologies of SA533B in $\mathrm{NaCl}-\mathrm{H}_{3} \mathrm{BO}_{3}$ solution after 14.4 ks immersion. 


\section{6. 考察}

最初に実験結果を考慮して反応機構を検討する.

$\mathrm{SA} 533 \mathrm{~B}$ の主成分は $\mathrm{Fe}$ であり，含有する他の金属成分は すべて Feより耐食性があるから，主なアノード反応は，

$$
\mathrm{Fe}=\mathrm{Fe}^{2+}+2 \mathrm{e}^{-}
$$

である. $\mathrm{H}_{3} \mathrm{BO}_{3}$ は不完全解離して弱酸性であるから, 溶液 内で

$$
\mathrm{H}_{3} \mathrm{BO}_{3}\left(=\mathrm{B}(\mathrm{OH})_{3}\right)+\mathrm{H}_{2} \mathrm{O}=\mathrm{B}(\mathrm{OH})_{4}{ }^{-}+\mathrm{H}^{+}
$$

の反応が進む. カソード反応は,

$$
2 \mathrm{H}^{+}+2 \mathrm{e}^{-}=\mathrm{H}_{2}
$$

である。したがって，主反応は，

$$
\mathrm{Fe}+2 \mathrm{H}^{+}=\mathrm{Fe}^{2+}+\mathrm{H}_{2}
$$

である.すなわち, 水素発生型の腐食である. $423 \mathrm{~K}$ の高温 であるから，水素過電圧は低いと思われる．実際，4h の実 験前後に溶液の $\mathrm{pH}$ を $298 \mathrm{~K}$ で測定すると, $\mathrm{pH}$ は 3.23 か ら 3.83 に変化したから, 腐食の進行に対応した水素イオン の消費になっている. 溶液内で, $\mathrm{Fe}^{2+}$ は加水分解し,

$$
\mathrm{Fe}^{2+}+4 / 3 \mathrm{H}_{2} \mathrm{O}=1 / 3 \mathrm{Fe}_{3} \mathrm{O}_{4}+2 \mathrm{H}^{+}+1 / 3 \mathrm{H}_{2}
$$

の反応で部分的に水素イオンが発生するから，反応はその分 たけさらに促進される。実験後の溶液は青みがかり， $\mathrm{SA} 533 \mathrm{~B}$ の表面も黒色であるから, 脱気雾囲気では $\mathrm{Fe}_{2} \mathrm{O}_{3}$ の生成までは腐食は進まない。したがって, 腐食初期の腐食 生成物はこの反応による $\mathrm{Fe}_{3} \mathrm{O}_{4}$ の生成と思われる. 酸素加 圧, また脱気せずに溶存酸素が残存する場合には, カソード 反応として，酸性溶液中では，

$$
1 / 2 \mathrm{O}_{2}+2 \mathrm{H}^{+}+2 \mathrm{e}^{-}=\mathrm{H}_{2} \mathrm{O}
$$

が進行する.この反応による寄与は Fig. 8 の酸素加圧の実 験で確認できた.

本研究は, $\mathrm{NaCl}-\mathrm{H}_{3} \mathrm{BO}_{3}$ 混合水溶液であるので, 塩化物イ オンの影響が加算される.

$$
\mathrm{Fe}^{2+}+\mathrm{Cl}^{-}=\mathrm{FeCl}^{+}
$$

の反応で, 溶液内に $\mathrm{FeCl}^{+}$イオンが形成される.これは溶 液中の $\mathrm{Fe}^{2+}$ イオン濃度を低下させるために, それだけ腐食 生成物が形成されにくく, $\mathrm{Fe}^{2+}$ が溶出しやすくなって腐食 が促進される.

$\mathrm{Fe}$ 表面の初期腐食生成物は $\mathrm{Fe}_{3} \mathrm{O}_{4}$ と考えられるが, 溶液 中のホウ酸イオンとの反応が起る. $\mathrm{Fe}-\mathrm{B}-\mathrm{O}$ 系に打ける複合 酸化物は多種類あるが16), $\mathrm{H}_{3} \mathrm{BO}_{3}$ 水溶液中で実験した場 合, 腐食生成物として $\mathrm{FeB}_{2} \mathrm{O}_{4}$ の形成が同定されている4 $\mathrm{FeB}_{2} \mathrm{O}_{4}$ が生成したとすれば， $\mathrm{Fe}^{2+}$ イオンと $\mathrm{B}(\mathrm{OH})_{4}^{-}$イオ ンが反応し, 脱水して

$$
\mathrm{Fe}^{2+}+2 \mathrm{~B}(\mathrm{OH})_{4}{ }^{-}=\mathrm{FeB}_{2} \mathrm{O}_{4}+4 \mathrm{H}_{2} \mathrm{O}
$$

の反応が進行すると考えられる. 本実験系でも $\mathrm{Fe}-\mathrm{B}-\mathrm{O}$ 系 の複合酸化物の生成は確認しているが，まだ組成の同定には 至っていない.

次に, SA533B と Ni-16Cr-7Fe 合金をガルバニ対にした 場合のガルバニ腐食の反応機構を考察する. 溶液内では両方 の試料を離して, 外部で結線した外部ガルバニ腐食と, 溶液 内で直接, 両金属を接続する内部ガルバニ腐食がある。 ず，外部ガルバニ腐食を考える. 自然浸漬電位が接近してい
るから，ガルバニ対になった場合，SA533B 上ではアノード 反応もカソード反応も起こるが, 先に示したようにカソード 支配型腐食で $\mathrm{Ni}-16 \mathrm{Cr}-7 \mathrm{Fe}$ 合金上ではアノード反応は無視 できる，全体としては， $\mathrm{pH}$ は上昇するが， $\mathrm{Ni}-16 \mathrm{Cr}-7 \mathrm{Fe}$ 合 金上ではカソード反応だけだから，その方が SA533Bより も $\mathrm{pH}$ は高くなるはずである.しかし, 離れているから, 相 手の試料上の反応との相互作用の影響を受けにくい．これに 対し, 溶液内で両試料を接続した Fig. 4 の内部ガルバニ腐 食では, 基本の反応は外部ガルバニ腐食と同一であるが, 両 試料が接する試料面上で $\mathrm{pH}$ 分布が不均一になる. 特に, 両 試料の境界で著しく変化する. Fig. 4 で内部ガルバニ試料の 接触界面で激しく反応したように見えるのはこの現象の反映 と思われる. 実験系は異なるが, 著者ら ${ }^{17)}$ が $\mathrm{Fe}$ 表面の一部 に $\mathrm{Zn}$ をめっきして中性の $\mathrm{NaCl}$ 水溶液中で $\mathrm{pH}$ 分布を測定 した結果によれば, $\mathrm{Zn}^{2+}$ イオンの溶出と加水分解に伴い, $\mathrm{Zn}$ 部の $\mathrm{pH}$ は低下し, $\mathrm{Fe} / \mathrm{Zn}$ 界面よりも $\mathrm{Fe}$ 側まで酸性域 が広がった。したがって, 本研究の Fig. 4 の場合も $\mathrm{SA} 533 \mathrm{~B} / \mathrm{Ni}-16 \mathrm{Cr}-7 \mathrm{Fe}$ 合金界面の $\mathrm{Ni}-16 \mathrm{Cr}-7 \mathrm{Fe}$ 合金側まで も酸性域が広がって腐食が進行する可能性がある.

SA533B を溶液に浸漬すると, Fig. 9 に示すように， $\mathrm{NaCl}$ 水溶液ではほとんど腐食せず, $\mathrm{H}_{3} \mathrm{BO}_{3}$ 水溶液中では腐 食し, 混合水溶液中では激しく腐食した. Fig. 6 のガルバニ 腐食実験で, 腐食電流は, $\mathrm{NaCl}$ 水溶液中ではほとんど流れ ず，そのため腐食せず, $\mathrm{H}_{3} \mathrm{BO}_{3}$ 水溶液中では流れ, 混合水 溶液中では増大した．実験手法は異なるが，よく対応してい る. 文献 7)では, $\mathrm{H}_{3} \mathrm{BO}_{3}$ 水溶液中の実験で $\mathrm{SA} 533 \mathrm{~B}$ それ自 体の激しい腐食と比べると，インコネル 600 とのガルバニ 腐食の寄与はそれほど重要でないと述べている。ただし,こ こで示したように, $\mathrm{H}_{3} \mathrm{BO}_{3}$ と $\mathrm{NaCl}$ を混合すると, ガルバニ 電流も増大する. 本研究で得られた平均的なガルバニ電流は $5 \mathrm{~A} / \mathrm{m}^{2}$ 程度で大きいわけではないが，ガルバニ腐食の寄与 についてはアノードとカソードの面積比の効果について注意 する必要がある。本研究では, アノードとなる SA533B と カソードの $\mathrm{Ni}-16 \mathrm{Cr}-7 \mathrm{Fe}$ 合金を同一面積の試料で実験し た.もし, 圧力容器のステンレス鋼，ニッケル基超合金の内 張りが破れたとすると，濃厚溶液になっていれば導電性がよ いから, 広い面積 $\left(S_{\mathrm{c}}\right)$ のカソードと破れたわずかな面積 $\left(S_{\mathrm{a}}\right)$ の SA533B アノードの組み合わせとなる. 近似的には, $S_{\mathrm{c}} / S_{\mathrm{a}}$ 比だけアノード電流が増加し, この比が 100 から 1000 になることも十分ありうるから，同一面積試料で測定 したガルバニ電流が小さくとも著しいガルバニ腐食になりう る.すなわち, 一度耐食性の内張り部分が少しでも破れて SA533B が水溶液と接すれば，集中的にアノード電流が流れ て，局部的により酸性となり，ドリル孔のような穴があく可 能性もある. そして, 一度貫通すると, 流動加速腐食が起り うる.このことを立証するためには，SA533Bの表面積に対 し広い表面積のニッケル基超合金を組み合わせて Fig. 4 に 示したような内部ガルバニ対試料で実験するのが有効と思わ れる。

本研究では行っていないが, 今後の検討事項を述べる.

本研究では高温, 高圧実験ということもあり, 小さい容積 で実験を行った，腐食が激しくなければ問題は少ないが，本 
研究のような激しい腐食が起る場合には, 容器サイズの影響 を受けやすい，溶出 $\mathrm{Fe}^{2+}$ イオン濃度が高けれげそれだけ腐 食生成物は形成されやすく, $\mathrm{Fe}^{2+}$ イオンの溶出が短時間で 抑制される. Table 3 で解析した自然浸漬の腐食量の場合, 表面積 $4 \mathrm{~cm}^{2}$ で $0.07 \mathrm{~mm} / \mathrm{h}$ であれば，実験した容器では 0.4 $\mathrm{mol} / \mathrm{h}$ の高濃度で $\mathrm{Fe}^{2+}$ イオンが溶出する。したがって, 腐 食時間が短い間は容器サイズの影響を受けにくいので，本研 究結果は腐食初期の值の信頼性が高いが，この小さい容器で 長期腐食実験を行えば，かえって腐食を過小評価する恐れが ある。しかし，大きい容器で実験をした方がよいと一概には 言えない，溶液が覺拌されにくくて濃縮する可能性がある状 況を模擬しようとすれば，小さい容器のほうが妥当な場合も ある. 原子炉圧力容器を模擬した大きいサイズの容器で実験 するのは容易でないから，容器サイズを変えた実験をして容 器サイズの影響を調べて外挿するのが望ましい.

水溶液が流動している時には保護性の皮膜が形成されにく く, 流動加速腐食が進行する. 原子炉の通常操業時にもこの 流動加速腐食が問題となりうるが ${ }^{18)}$, 圧力容器の底に穴が あけば，漏水が高速で流れて流動加速腐食は深刻になると予 想される. 仮に, $423 \mathrm{~K}$ で圧力容器内外の差圧が $0.4 \mathrm{MPa}$ で，水を $5 \mathrm{~m}$ の高さまで貯えたとすると，トリチェリーの 公式で得られた流速 $\sqrt{2 g h}$ は，約 $30 \mathrm{~m} / \mathrm{s}$ の高速になる。た だし，高速で水溶液が流出するということは，それだけ溶液 が濃縮される可能性が低くなるから, 両方の相反する効果の どちらが優先するかは不明である.

海水と“ホウ酸” が注入された溶液系は，一般には $\mathrm{NaCl}-$ $\mathrm{H}_{3} \mathrm{BO}_{3}-\mathrm{Na}_{2} \mathrm{~B}_{4} \mathrm{O}_{7}$ 系である。本研究では，極端に酸性化する 可能性を考慮して $\mathrm{NaCl}-\mathrm{H}_{3} \mathrm{BO}_{3}$ 系を選んで実験を行った. その結果，SA533Bの腐食は激しく, Fig. 4 で示したように, $\mathrm{SA} 533 \mathrm{~B}$ と $\mathrm{Ni}-16 \mathrm{Cr}-7 \mathrm{Fe}$ 合金が直接接し，その間に隙間が 生じれば，そこがより酸性化して，その部分の腐食が加速す る可能性を明らかにした．実際の圧力容器で広い面積の力 ソードとなるステンレス鋼やニッケル基超合金にわずかに亀 裂が入り，SA533Bが現れれば，その腐食性は一気に加速す る. 今後は $\mathrm{NaCl}-\mathrm{H}_{3} \mathrm{BO}_{3}-\mathrm{Na}_{2} \mathrm{~B}_{4} \mathrm{O}_{7}$ 系の幅広い組成でこの腐 食性を調べる必要がある。

本研究では，原発事故が起こり $373 \mathrm{~K}$ までの冷温停止が 図られるまでの状況を模擬した腐食実験を行った。現状で は, 冷却水は淡水であり, 水の蒸発も少なくなっているか ら，溶液が濃縮される可能性も低くなっている。しかし，事 故発生から少なくとも 2 ヶ月間は圧力容器は激しい腐食環 境に懪され，その履歴は残り，その後に腐食環境が緩和され たとしても，それまでの履歴の影響が残ると思われる．本研 究で示したように，密着性の悪い腐食生成物ができれば，そ の間に $\mathrm{NaCl}$ ，ホウ酸塩などが混じり，より腐食性の低い溶 液環境に改善されたとしても簡単には安定な皮膜は生成しな いと思われる. 事故圧力容器に関する腐食の研究では, 圧力 容器が受けた履歴を考慮した研究が必要と考える.

\section{7. 結 言}

これまでの結果をまとめると，次のようになる.
福島原発事故炉には，緊急事態として，圧力容器に海水， “ホウ酸”が注入されたので，その混合水溶液系の基本は， $\mathrm{NaCl}-\mathrm{H}_{3} \mathrm{BO}_{3}-\mathrm{Na}_{2} \mathrm{~B}_{4} \mathrm{O}_{7}$ 系である. 圧力容器に用いられる材 料である SA533B とインコネル 600 の組成の $\mathrm{Ni}-16 \mathrm{Cr}-7 \mathrm{Fe}$ 合金について，加速腐食実験をするための適切な実験条件を 考察し, $423 \mathrm{~K}, \mathrm{NaCl}$ (飽和) $-\mathrm{H}_{3} \mathrm{BO}_{3}$ (濃厚) 水溶液で自然浸 漬腐食とガルバニ腐食の程度を調べることにした。

その実験結果から，SA533Bの腐食について，

(1) $\mathrm{NaCl}$ 水溶液中ではあまり腐食せず, $\mathrm{H}_{3} \mathrm{BO}_{3}$ 水溶液中 では激しく腐食し， $\mathrm{NaCl}-\mathrm{H}_{3} \mathrm{BO}_{3}$ 混合水溶液中になるとさら に腐食は激しかった。

(2) インコネル 600 組成の $\mathrm{Ni}-16 \mathrm{Cr}-7 \mathrm{Fe}$ 合金とガルバニ 対になると腐食はさらに加速した。

（3）今回得られた初期腐食速度は $0.07 \sim 0.08 \mathrm{~mm} / \mathrm{h}$ で, そのまま腐食が進むと仮定すると $60 \sim 70 \mathrm{~cm} / \mathrm{y}$ となる。

（4）保護皮膜は生成されにくく，腐食が持続しやすい. などの知見が得られた。

そして，より現実的な実験条件で検証していく必要がある が，激しく腐食する可能性があることを明らかにし，今後に 進めるべき実験についても若干の考察をした.

\section{文献}

1) The evaluation status of reactor core damage at Fukushima Daiichi nuclear power station units 1 to 3, (Tokyo Electric Power Company, Nov. 30, 2011): http://www.tepco.co.jp/nu/ fukushima-np/images/handouts _ $111130 \_07$-j.pdf

2) Seismic damage information in the period Mar. 11-Jul. 31, (Nuclear and Industrial Safety Agency, Sep.1, 2011): http:/ www.meti.go.jp/press / 2011/09/20110901006/20110901006$6 . p d f$

3) NRC information notice 2002-11 (US Nuclear Regulatory Commission, Washington, 2002): http://www.nrc.gov/reading$\mathrm{rm} /$ doc-collections/gen-comm/info-no tices/2002/in02011. html

4) NUREG/CR-6875 (US Nuclear Regulatory Commission, Washington, 2005) pp. 1-48.

5) Interim report of the Investigation Committee on the accident at the Fukushima nuclear power stations of Tokyo Electric Power Company, (Dec.26, 2011) pp. II-13.

6) Technical assessment of aging: On unit 1at the Fukushima nuclear power stations of Tokyo Electric Power Company (Japan Nuclear Energy Safety Organization, Feb. 3, 2011) http://plec.jnes.go.jp/vlr index.html

7) T. Kodaira: Tetsu-to-Hagane 73(1987) 1656-1667.

8) T. Takeuchi, A. Kuramoto, J. Kameda, T. Toyama, Y. Nagai, M. Hasegawa, T. Ohkubo, T. Yoshiie, Y. Nishiyama and K. Onizawa: J. Nucl. Mater. 402(2010) 93-101.

9) NUREG/CR-6988, (US Nuclear Regulatory Commission, Washington, 2009) pp. 33-35.

10 ) NUREG-1823, (US Nuclear Regulatory Commission, Washington, 2005) pp. 3-19.

11) Kirk-Othmer: Encyclopedia of Chemical Technology, Vol. 4, (John Wiley and Sons, Inc., New York, 1978) p. 85.

12) W. F. Linke: Solubilities: Inorganic and Metal-Organic Compounds, Vol. II, (Van Nostrand, New York, 1958) p. 959.

13) W. F Linke: Solubilities: Inorganic and Metal-Organic Compounds, Vol. I , (Van Nostrand, New York, 1958) p. 262.

14) G. D. Giacomo, P. Brandani, V. Brandani and G. D. Re: Desalination 91 (1993) 21-33.

15) T. Nakagawa: J. Japan Inst. Metals 68(2004) 14-20.

16) J. S. Knyrim and H. Huppertz: J. Solid State Chem. $181(2008)$ 2092-2098

17) E. Tada, K. Sugawara and H. Kaneko: Electrochim. Acta 49 (2004) 1019-1026.

18) NRC information notice 97-84, (US Nuclear Regulatory Commission, Washington, 1997): http://www.nrc.gov/reading$\mathrm{rm} /$ doc-collections / gen-comm / info-notices / 1997 / in97084 html 